\title{
THREE NEW SPECIES OF ROPALIDIA GUERIN (HYMENOPTERA: VESPIDAE) FROM SOUTHERN INDIA
}

\author{
Lambert Kishore ${ }^{1}$, T.C. Narendran ${ }^{2,3}$ and P. Girish Kumar ${ }^{2,4}$ \\ ${ }^{1}$ Department of Zoology, Malabar Christian College, Kerala 673001, India. \\ ${ }^{2}$ Systematic Entomology Laboratory, Department of Zoology, University of Calicut, Kerala 673635, India \\ Email: ${ }^{3}$ drtcnarendran@yahoo.com (corresponding author); ${ }^{4} \mathrm{k}$ p p girish@yahoo.co.in
}

\begin{abstract}
Three new species viz., Ropalidia (Anthreneida) bangalorica Lambert and Narendran sp. nov., $R$. (A.) indica Lambert and Narendran sp. nov. and $R$. (A.) rodialipa Lambert and Narendran sp. nov. are described in this paper from southern India. Comparison with related species are also provided. $R$. (A.) bangalorica Lambert and Narendran sp. nov. can be distinguished from other species in having second metasomal tergite not petiolate and propodeum without close fine striations. $R$. (A.) indica Lambert and Narendran sp. nov. differs from other species in having temple smaller than eye in profile, second metasomal tergite without yellow marking at base and mesosoma and metasoma reddish-brown. $R$. (A.) rodialipa Lambert and Narendran sp. nov. can be distinguished in the presence of following combination of characters: median line of median groove of propodeum not distinct, temple distinctly shorter than eye in profile, absence of yellow mark on interantennal space and metasomal petiole with apical yellow band .
\end{abstract}

\section{KeYwords}

Hymenoptera, Vespidae, Ropalidia, new species, India.

\section{AbBreviations}

DZUC - Department of Zoology, University of Calicut; ZSIK - Western Ghats Regional Station, Zoological Survey of India, Kozhikode.

The genus Ropalidia was described by Guerin (1831) with type species Ropalidia maculiventris. Later Saussure (1853-58) and Bingham (1897) contributed to the study of the Indian species under different names. The genus Ropalidia Guerin (1831) is widely distributed throughout the warmer parts of the old world. So far 34 species have been described from the Indian subcontinent. In this paper we describe three new species from southern India, which do not fit in the key of Das and Gupta (1989) or the descriptions of any species so far known from the world.

Holotypes are deposited at Department of Zoology, University of Calicut (DZUC) but eventually will be transferred to Western Ghats Regional Station, Zoological Survey of India, Kozhikode (ZSIK).

\section{Ropalidia (Anthreneida) bangalorica Lambert and Narendran sp. nov.}

(Figs. 1-5)

\author{
Material examined \\ Holotype: Female, 12.viii.1996, Bangalore (12058'N \& 77035'E), \\ Karnataka, coll. O.K. Remadevi, LK 103 (DZUC).
}

\section{Etymology}

Named after the type locality.

\section{Diagnostic features}

Female: Length $8 \mathrm{~mm}$. Brown with yellow and black markings.

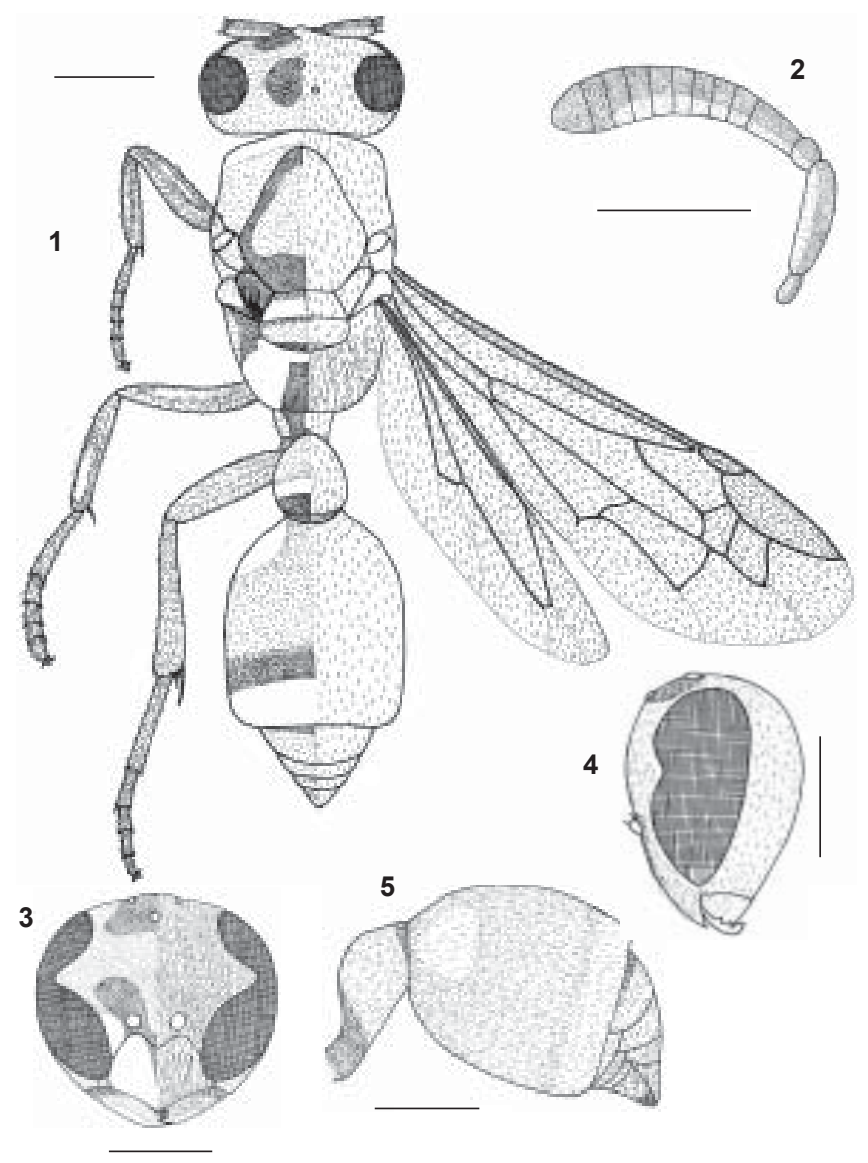

Figures. 1-5. Ropalidia (Anthreneida) bangalorica Lambert and Narendran sp. nov. (Female). Scale $=1 \mathrm{~mm}$.

1 - Body dorsal view; 2 - Antenna; 3 - Head front view; 4 - Head lateral view; 5 - Metasoma

(C) Zoo Outreach Organisation; www.zoosprint.org Manuscript 1295; Received 01 December 2004; Revised received 25 May 2005; Finally accepted 02 June 2005 ; Date of publication 21 June 2005 
Yellow markings as follows: clypeus except centre, two lines on lower margin of mandible, lower sides of antennal scape and flagellomeres, a marking between toruli, a line towards ocular sinus, a line on anterior margin of pronotum, two spots on upper margin of scutellum, a pair of spots on postscutellum, two elongated marks on sides of propodeum, pale band on apical margin of metasomal petiole, a broad band on apical margin of second metasomal segment, an irregular spot on base of second metasomal segment on sides, fourth and fifth segment with pale apical band, fore coxa completely, mid coxa partially, hind coxa sides, a line on fore femur and fore tibia, a line on mid tibia and hind tibia. Black markings as follows: a line on base of mandible, middle region of clypeus, upper emargination of clypeus, a pair of line just above antennae towards ocular sinus, triangular mark enclosing ocelli, a spot on side of pronotum, inner margin of mesocutum broadly, a spot below tegula, margins of meso and metapleuron, upper margins of scutellum and postscutellum, middle of propodeum, upper sides of propodeum, base of the petiole, base of second metasomal segment. Wings hyaline; apex of radial cell and stigma brown; veins brown.

Head: (Figs. 1, 3 and 4) Covered with short silvery pubescence; width in anterior view $1.25 \mathrm{x}$ as long as distance between front ocellus and lower labral margin (Fig. 3), head width in dorsal view 3.06x distance between front ocellus and posterior occipital margin, wider than mesosoma (46:42); clypeus wider than long medially (27:19.5) (Fig. 3), apical area with long hairs, apical margin pointed, upper margin emarginated, moderately close shallow punctures; mandible with few scattered fine superficial punctures, long hairs; supraclypeal area, interantennal space, inner orbit of ocular sinus, vertex and temple with fine superficial punctures; inter spaces between punctures smooth; in yellow area interspace larger than diameter of puncture; interocular distance more on vertex than at clypeus $(36.5: 26.5)$; interocellar distance $0.62 \mathrm{x}$ ocellocular distance and $4 \mathrm{x}$ diameter of posterior ocellus; temple distinctly narrower dorsally towards vertex (Fig. 4) and smaller than eye in profile; antennae $0.76 \mathrm{x}$ farther from eyes than to each other; antenna with scape length $2.2 \mathrm{x}$ length of first flagellar segment; second flagellar segment $2.25 \mathrm{x}$ as long as first flagellar segment (Fig. 2), 0.6x as long as wide at apex; apical antennal segments $1.35 \mathrm{x}$ wider than long; all other segments subequal.

Mesosoma: (Fig. 1) Stout; covered with silvery pubuscence; pronotum, mesoscutum and mesopleuron behind epicnemial carina closely and reticulately punctate; sides of postscutellum and scutellum with deep punctures; epicnemial carina not distinct; ventral metapleuron with moderately close deep punctures, with a few strong oblique striations; propodeum without lateral carinae, without close fine striations; hairs on propodeum larger towards posterior.

Metasoma: (Figs. 1 and 5) Metasomal petiole shorter than hind femur, strongly swollen just after end of basal slit; second metasomal tergite slightly longer than wide (46.5:41), normal and not petiolate, obliquely cut off at apex.
Male: Unknown.

Host Insect: Inglisia bivalvata Gr. (Hemiptera: Coccidae).

Host Plant: Santalum album Linn. (Family: Santalaceae).

Biology: Unknown.

\section{Discussion}

This new species comes closer to Ropalidia (Anthreneida) fasciata (Fabricius) in the key to the subgenera and species occurring in the Indian subregion by Das and Gupta (1989). However it differs from $R$. (A.) faciata in the following characters: (i) In $R$. (A.) bangalorica the second metasomal tergite normal and not petiolate (In $R$. (A.) faciata second metasomal tergite petiolate; (ii) In $R$. (A.) bangalorica propodeum without close fine striations (In $R$. (A.) faciata propodeum with striations); (iii) In $R$. (A.) bangalorica a broad yellow line on temple absent (In $R$. (A.) faciata a broad yellow line present); (iv) In $R$. (A.) bangalorica scutellum and postscutellum partially yellow coloured (In $R$. (A.) faciata scutellum and postscutellum entirely yellow); and (v) In $R$. (A.) bangalorica a yellow spot present on interantennal space, not exceeding frons. (In $R$. (A.) faciata a yellow mark present between the antennae and exceeding towards frons.

\section{Ropalidia (Anthreneida) indica Lambert and Narendran sp. nov.} (Figs. 6-10)

\section{Material examined}

Holotype: Female, 26.i.1994, Kasaragod (12030'N \& 74059'E), Kerala, India, coll. K. Gopi, LK 101 (DZUC).

Paratype: Female, 26.i.1994, same as holotype, LK 102 (DZUC).

\section{Etymology}

Named after the country of origin.

\section{Diagnostic features}

Female: Length $13.08 \mathrm{~mm}$. Reddish-brown with yellow and black markings. Yellow markings as follows: apical margin of clypeus irregularly; base of mandible broadly; a line below antennal scape, seven to twelve segments of the antenna entirely, mid anterior margin of pronotum, apical margin of metasomal petiole and second metasomal segment faintly, all tarsi, hind tibia and upper region of fore tibia. Black markings as follows: a spot at centre of clypeus, apical margin and emargination; just above antennal socket, frons, vertex enclosing ocelli, outer margin of mesoscutum and an irregular mark from anterior side to posterior side, just below wings, mesopleuron and metapleuron, almost all mesosomal sutures, ventral sides of meso and metapleuron. Wings yellowish; three fourth of radial cells and last cubital cell blackish-brown; stigma yellow; veins dark brown.

Head (Figs. 6, 8 and 9). Covered with short silvery pubescence; width in anterior view $1.31 \mathrm{x}$ as long as distance between front ocellus and lower labral margin (Fig. 8), head width in dorsal view 3.9x distance between front ocellus and posterior occipital 


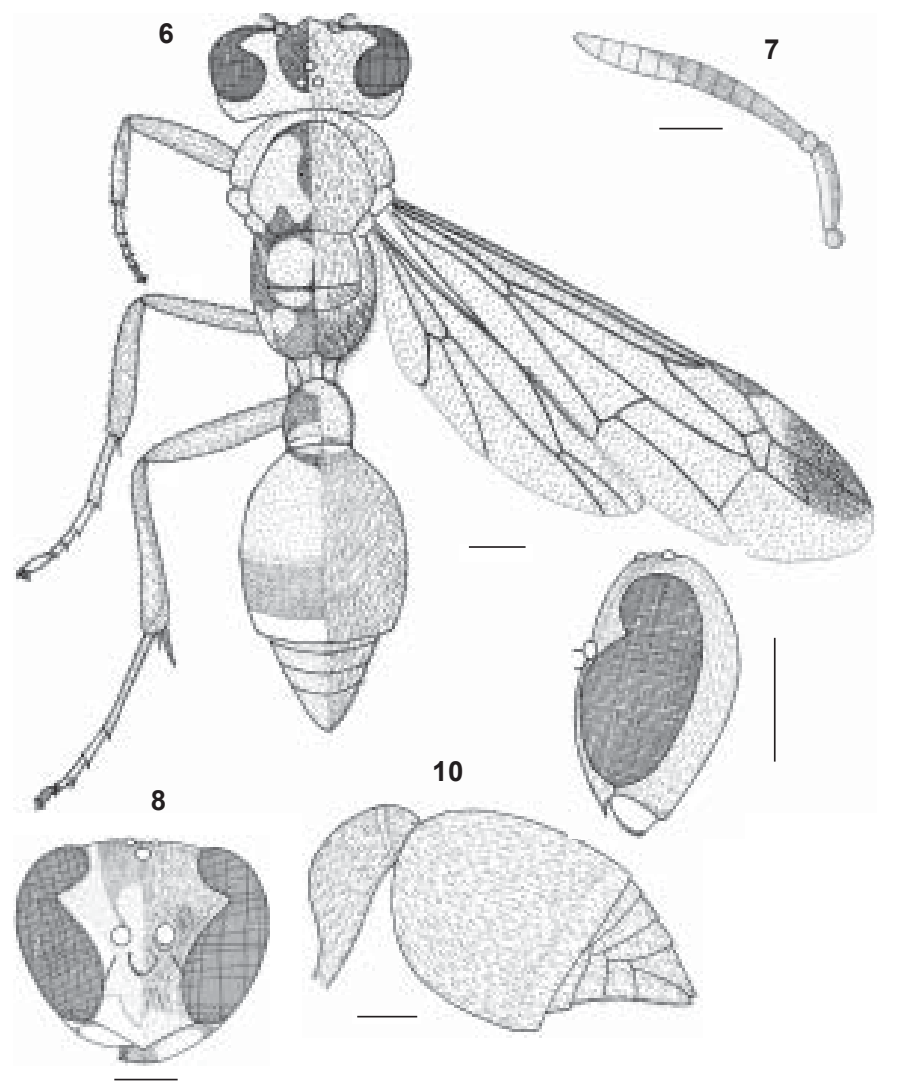

Figures 6-10. Ropalidia (Anthreneida) indica Lambert and Narendran sp. nov. (Female). Scale $=1 \mathrm{~mm}$.

6 - Body dorsal view; 7 - Antenna; 8 - Head front view; 9 - Head lateral view; 10 - Metasoma

margin, wider than mesosoma (44:36); clypeus wider than long medially (26:21) (Fig. 8) with long hairs on apical margin, pointed, upper margin emarginate, with few scattered punctures; mandible with scattered punctures; supraclypeal area, interantennal space, inner orbit, ocular sinus, vertex, and temple moderately punctate; temple with long silvery hairs; interocular distance more on vertex than at clypeus (32:22.5); interocellar distance $0.23 \mathrm{x}$ as long as ocellocular distance and as equal as diameter of posterior ocellus; temple distinctly narrower dorsally towards vertex and smaller than eye in profile (Fig. 9); antennae farther from each other than from eyes (7:5), antenna with scape length $1.4 \mathrm{x}$ length of first flagellar segment; second flagellar segment $0.35 \mathrm{x}$ as long as first flagellar segment (Fig. 7), 0.93x as long as wide at apex; apical antennal segment $1.38 \mathrm{x}$ longer than wide, all other segments subequal.

Mesosoma (Fig. 6). Stout; covered with silvery pubescence; pronotum, mesonotum, scutellum, postscutellum (except a triangle mark on centre) and mesopleuron strongly punctate; ventral metapleuron smooth with few scattered punctures, side of ventral metapleuron with striations, propodeum with long hairs and lateral carinae, covered with fine silvery hairs, reticulately punctate.

Metasoma (Figs. 6, 10). Metasomal petiole longer than hind femur, second metasomal tergite longer than wide (43.5:36).

Male: Unknown.

Biology: Unknown.

\section{Discussion}

This new species comes closer to Ropalidia (Anthreneida) ruficollaris (Cameron) in the key to the subgenera and species occuring in the Indian sub region by Das \& Gupta (1989). However, it differs from $R$. (A.) ruficollaris in the following characters: (i) In $R$. (A.) indica temple smaller than eye in profile (in $R$. (A.) ruficollaris temple as equal as eye in profile); (ii) Second metasomal tergite in $R$. (A.) indica without yellow marking at base (In $R$. (A.) ruficollaris second metasomal tergite with yellow marking at base); (iii) In $R$. (A.) indica last six (apical) flagellomeres of the antenna yellow (In $R$. (A.) ruficollaris apical six flagellomers of the antenna black above); (iv) In $R$. (A.) indica apical margin of the clypeus yellow (In $R$.(A.) ruficollaris a triangular mark present at apical margin of clypeus; and (v) In

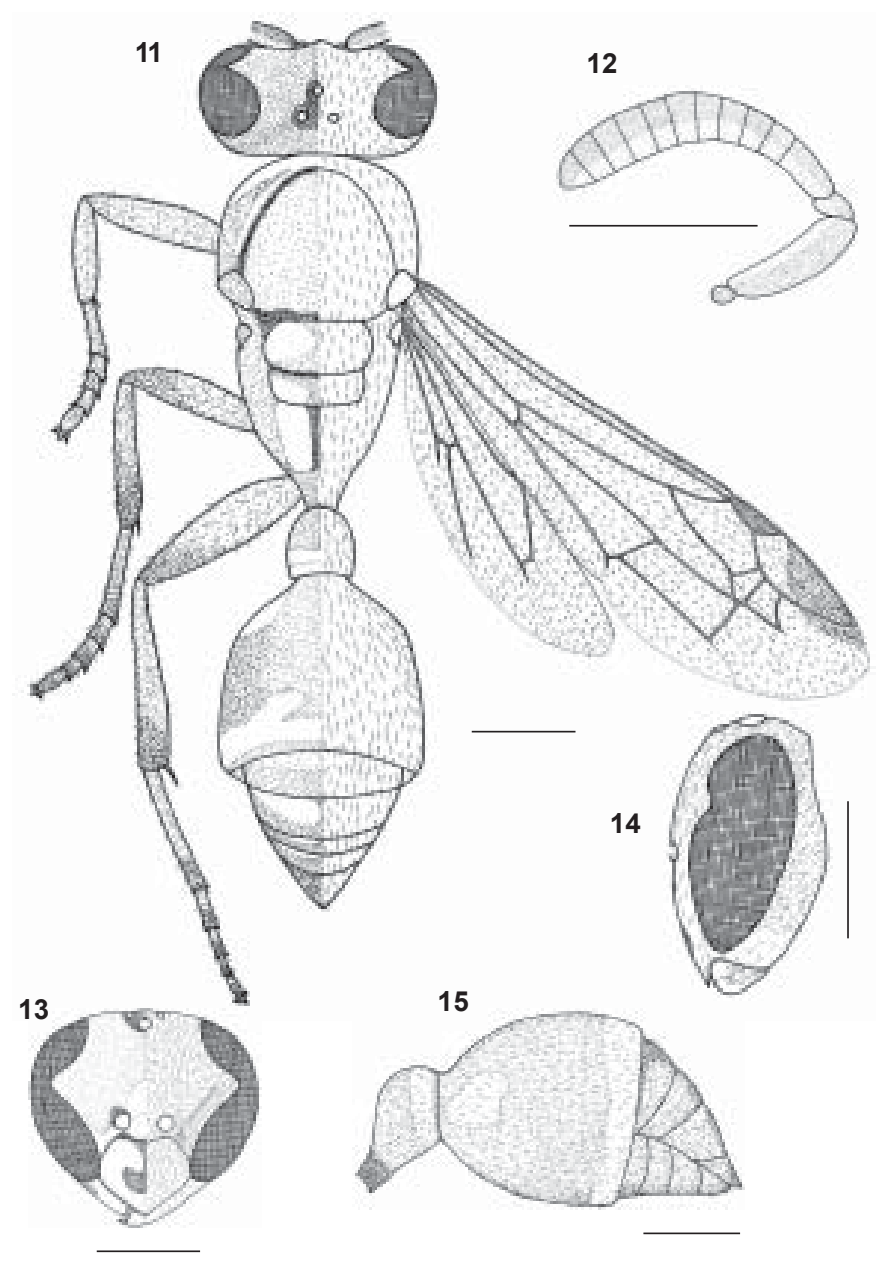

Figures 11-15. Ropalidia (Anthreneida) rodialipa Lambert and Narendran sp. nov. (Male). Scale $=1 \mathrm{~mm}$.

11 - Body dorsal view; 12 - Antenna; 13 - Head front view; 14 - Head lateral view; 15 - Metasoma 
$R$. (A.) indica mesosoma and metasoma reddish-brown (In $R$. (A.) ruficollaris mesosoma and metasoma black).

\section{Ropalidia (Anthreneida) rodialipa Lambert and Narendran sp. nov.}

(Figs. 11-15)

\section{Material examined}

Holotype: Male, 19.viii.2000, Elathur [1 $\left.11^{\circ} 20^{\prime} \mathrm{N} \& 7^{\circ} 44^{\prime} \mathrm{E}\right]$, Kozhikode District, Kerala, coll. Sreedharan, LK 104 (DZUC). Paratype: Male, 8.viii.2001, same as holotype, LK 105 (DZUC).

\section{Etymology}

Species name is an anagram of Ropalidia.

\section{Diagnostic features}

Male: Length $8.55 \mathrm{~mm}$. Reddish-brown with yellow markings. Yellow markings as follows: upper sides of mandible, clypeus entirely except an irregular spot on centre, a line below antennal scape, interantennal space, basal margin of pronotum, fore coxa and hind coxa almost entirely, lower sides of fore femur and hind femur, propodeum except centre, metasomal petiole and second metasomal tergite with narrow apical fascica, pale yellow bands on third, fourth and fifth metasomal tergite. Brown markings as follows: an irregular spot at centre of clypeus, base of mandible, margins of mesoscutellum and at centre of propodeum. Wings yellowish hyaline; apical half of radial cell dark brown; stigma yellow.

Head: (Figs. 12, 14 and 15). Covered with short silvery pubescence; width in anterior view $1.23 \mathrm{x}$ as long as distance between front ocellus and lower labral margin (Fig. 13); head width in dorsal view 4.1x distance between front ocellus and posterior occipital margin, wider than mesosoma (41:35); clypeus wider than long medially (25.5:21.5) (Fig. 13), with small hairs, shiny, pointed, upper margin slightly curved, with few scattered punctures; mandible with scattered punctures; supra clypeal area, interantennal space, inner orbit and ocular sinus smoothly punctate; frons and temple strongly and reticulately punctate; interocular distance more on vertex than at clypeus (32.5:25.5); interocellar distance $0.66 \mathrm{x}$ as long as ocellocular distance, $2 \mathrm{x}$ diameter of posterior ocellus; temple slightly narrower dorsally towards vertex and smaller than eye in profile (Fig. 14); antennae not farther from each other than eye (7.5:7); antennae with scape length $2.88 x$ length of first flagellar segment; second flagellar segment $0.41 \mathrm{x}$ as long as first flagellar segment (Fig. 12), 0.7x as long as wide at apex; apical antennal segment $1.37 \mathrm{x}$ wider than long; all other segments subequal.

Mesosoma: (Fig. 11). Stout; covered with silvery pubescence; long whitish hairs at posterior side of propodeum; pronotum, mesonotum and mesopleuron closely and strongly punctate; metapleuron with strong striations; propodeum without striations; median line of median groove of propodeum not distinct; postscutellum declive, placed below level of scutellum.

Metasoma: (Figs. 11 and 15). Metasomal petiole shorter than hind femur (Fig. 11); second metasomal tergite wider than long
(35.5:31); all metasomal segments reticulately punctate, covered with fine silvery hairs.

Female: Unknown.

Biology: Unknown.

\section{Discussion}

This new species comes closer to Ropalidia (Anthreneida) jacobsoni (Buysson) in key to the subgenera and species occuring in Indian subregion by Das and Gupta (1989). However it differs from $R$. (A.) jacobsoni in the following characters: (i) In $R$. (A.) rodialipa median line of median groove of propodeum not distinct (In $R$. (A.) jacobsoni the median line of median groove of propodeum distinct); (ii) In $R$.(A.) rodialipa, a yellow mark on interantennal space absent (In $R$. (A.) jacobsoni a yellow mark on interantennal space present); (iii) In $R$. (A.) rodialipa metasomal petiole with apical yellow band (In $R$. (A.) jacobsoni metasomal petiole without yellow band); and (iv) In $R$. (A.) rodialipa temple distinctly shorter than eye in profile (In $R$. (A.) jacobsoni temple slightly shorter than eye in profile.

\section{REFERENCES}

Bingham, C.T. (1897). Fauna of British India, including Ceylon and Burma, Hymenoptera, Vol. 1. Waps and Bees. xxix +577 pp. +4 pls. London: Taylor and Francis.

Das, B.P. and V.K. Gupta (1989). The Social Wasps of India and the adjacent countries (Hymenoptera: Vespidae). Oriental Insects Monograph 11: 1-292.

Guerin-Meneville, F.C. (1831-38). Crustacees, Arachnides et insects. In: Duperrey, L.J., "Voyage author du Monde sur la Coq uille (182225)". Zoologia 2(2), Div. I. Paris. 319pp.

Saussure, H.F. de (1853-58). Monographie des Guepes Sociales ou de la Tribu des Vespiens. Etudes sur la Famille des Vespides, Vol. 2. Paris \& Geneva

\section{Acknowledgement}

We are grateful to Dr. Carpenter J.H., American Museum of Natural History, New York, for providing some of the valuable reprints and other useful information for our research. We thank the authorities of University of Calicut for facilities provided. We are also grateful to Prof. Raghavendra Gadagkar, Indian Institute of Science, Bangalore for some useful reprints and for permitting to consult the library of the Centre for Ecological Sciences. 